\title{
鋼の燒入に關する新理論(其の三)
}

$\begin{array}{cccc}\text { 會 } & \text { 崱 } & \text { 瀨 慶 } & \text { 三 } \\ \text { 曾 } & \text { 竹 } & \text { 內 } & \text { 策 }\end{array}$

\section{、、 新理論による睹現泉の說明}

\section{§1.䥔の自硬性と所謂マス} \section{エフェクトの基新}

(1) 自硬性

炭素鋼卆マルテン化するには，

(1) $A_{1}$ 變熊 $\boldsymbol{\Upsilon}$ 阻止すること。

（2）格子戀態の可能なる溫度にオーステ ナイトを持來方こと。

の二つの條件が必要である。初析晶の存在を するくする場合には（1）の $\mathbf{A}_{\mathbf{1}}$ 變態の外に $\mathbf{A}_{\mathbf{z}}$ 又は $\mathrm{Ac}_{m}$ 變熊をす阻止する必要がある。而 して(1)の目的のために急冷をなし，(2)の目 的のために燒入液を零度に選んだり，或は燒 入後更に低溫度に迄冷却するのである．然る にニッケルークロム鋼やこの他の或種の特殊鋼 に於てはオーステナイト狀態から急冷する必 要なく, 徐冷してを常楹に於てマルテンサイ トが得られるのである。帠占急冷と云ふ汃如 き特別の熱處理をせすとも，空中放冷程度の 泠却の仕方によつても，獨りてにマルテンサ イトを生するのである。斯樣な鋼劣自硬鋼 Self-hardening steel と云ふ.

この自硬性の由って來るところに關して は，いろいろの研究がある类，それらは單に 自硬性の現象を粼測するに止つてるると言ふ ひくくまだ十分なる說明は與へられてるな゙ いこれらの自硬鋼に於ては，變態點が降下
してるるから自硬性を示すのであると說明せ られてるるが,これは說明になってるない。 何となればこれらの說明では單に熊態點と 云ふのみて，その意味る明らかにしてわない がら, $A_{1}$ 變態點のことか, マルテン化の盜 度のことか不明てある。若しもこれる $\mathrm{A}_{1}$ 變 態點郎与共析租化點意味するものとすれ ばこの温度が降下したとしても，バーライ 卜類の共析晶を生すべざあつて，マルテン サイト卓生する說明とはならない，況んや急 冷せすとも空冷でマルテン化する說明とはな らない. 又變態點の意味をマルテン化の溫度一 と解㯢しても，幾らこれか低溫度となってる て。，空冷の途中で共析督化が起きればマル テンサイトは出來なくなるから，自硬性の原 因をマルテン化の溫度が低くなつたからであ るとする說明を矢張り說明になつてるない。 マルテン化の温度の高低と、ルテン化の難易 との關係は，虽う高溫程たやすいと考へるの が常識である．從つて自硬性の說明として變 態點の降下を云々することは理論的に無意味 である。それのみでなく、これらの說明は實 際とす合ってるない. 何となれ第 7 圆の ころに述べた如く炭素鋼のハイパー鋼に於け さマルテン化の溫度は，常溫附近及びそれ以 下である。郎ち著しく低い，それにす拘らす 
この鋼には自硬性少ない，然るに所謂自硬銅 の๙ルテン化り溫度法，これに比べて決して 低くなく护う高いものちらあるのである。

新理論によ礼ば, 自硬性の由つて来るとこ うは極めて簡單である。鋼るマルテン化する に沈オーステナイト狀熊を過冷业七かて，格 子變態點以下に持來ちこ反が必要なのですつ $\tau$ ，炭素錩に於て急冷必必要とするのは， オニステナイト垫過冷せしるる目的に外なら

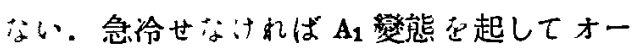
ステナイトか分解して了的占でる．然る

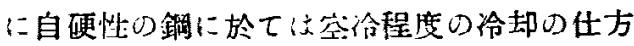
によつて艺，オーステナイト小易く過泠せら れ得るから，之机か格子變熊點以下となつて マルテン化するりである。郎ち自硬性つ由つ て來るところは，オーステナイトの過冷を妨 げるか如き變化 ( $\mathrm{A}_{1}$ 變態的如き搬散を必要と

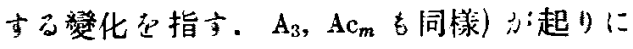
くいこにある。公さ换へれば擴散の起りに くいと云心性質ふ自硬州它招來してるるので ある。

この自硬性い現像法，钱一二ッケル合金に於 ても,はつきり認められるひである.㖪ーニッケ ル合金に玷ては，撨散現像か起りにくいいで, 晋通の $\mathrm{A}_{3}$ 變態はニッケルの多いものに於て 没なかなか起りにくいるていたるにオー ステナイト狀熊から徐冷しても, 殆ど $\boldsymbol{\alpha}$ 固溶 體さ析出うることなくして過冷せられ，格子

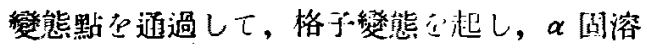
體となつて了ふ。斯くして生じた $\boldsymbol{a}$ 周溶體 はマルテンサイト類似の組織它持つてるる。

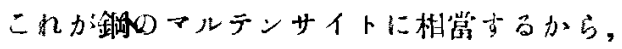

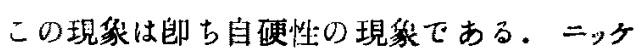
ル少少いと云ふと，第 4 圖にす示如く，飞 の $A_{3}$ 變態曲線 $G B, G A$ の溫度㳘いから, 徐

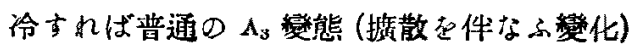
杂指賞に進行するから，餘り自硬性は顯著て ない. $20 \%$ 位のニッケルを舍む合金になると， $A_{3}$ 變態溫度も低くなるから，揗散も進行しに くい，從つて空冷程度の泠却で格子變態飞起

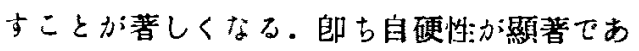
る. $30 \%$ ニケル含むすのになる，徐冷 しても殆ど格子變態によつてのみ $\boldsymbol{\alpha}$ となる に過さない。即古完全な自硬性㬱す。

鐵ーニっケル合金の昜合には，假命朎却の途 中に於て普通の $A_{3}$ 變態起すとしても,こ 叔名十分に進行せない限りニッタルに富む オーステナイトか殘留するからこのるの蚂 冷却し續ければ，三机势ＧA線以下に泠却せ

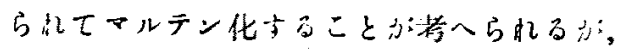
鋼以塄合には $\mathbf{A}_{1}$ 数態を起せばオーステナイ トは心くはつて了ふから，マルテンサイトを 得るには， $A_{1}$ 變態尼起させないことが縃對に 必要である。このために岑秦銅では急冷する のである。自硬州鋼では徐冷しても $A_{1}$ 變態 か郌りにくいので,オーステナイト招ルテ ン化の温度まで過冷上られここでルテン サイトとなるのである。即ちマルテン化の温 破迄オーステナイト過冷せしめると云ふこ とが燒入す必須條件でこのために炭秦鍓で

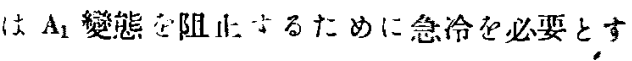
るのである。

以上认說明に便なるきう $A_{1}$ 變態の阻止の

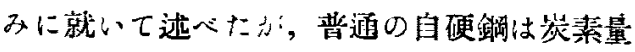




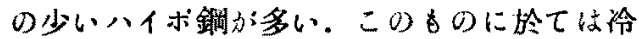
却の際に先つ初析戀化として $A_{3}$ 變態在起し, 然る後に $A_{1}$ 態態起すものであら。從つて 十分ふる自硬性としてはこの $A_{3}$ 變態门徐 冷(察冷)に際して起すしとなくオーステナ イト招己りま〉格子變熊のみにようてトルテ

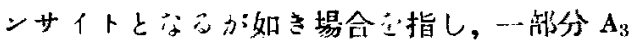

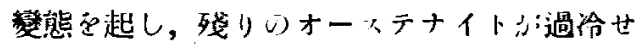

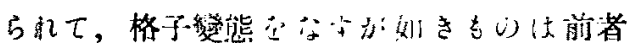
に比バれば自硬性少艄、少ると云ふぐきであ らう.

IV. \$1.（1）に述バた如くー一般にオーステナ イトよりの異相變化汶結品粒の界等に玷て起 り易いとせら乱っむ。從つて結昂䊀つ中心 は筧全な自硬現湬方方与，粒界に於ては多

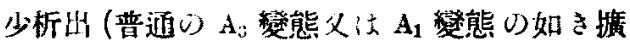

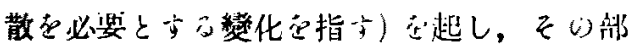
分はオーステナイト少殘留したり，序狀共所

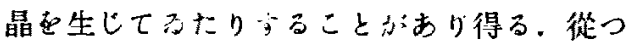
て普通に云はれてるる自硬龬といへどる くこの點調心゙い上初析晶少出てうたり， オーステナイト镈留してみたりすることが あり得る。

以上に述へた如く, 自硬性の由つて來ると ころ流，析出變化を起しにくいこと郎方旗散

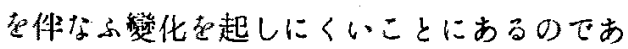
つて, 從來将へられてらた如き變態點の䧏下 によるのではないのである。

\section{（2） マスエフェクトとニッケル代用制}

以上に述心て來たことからして，所㯰マス エフェクトの意䔐も明らかになつたこをと思 はれる、啔にマスエフェクトと云八ば、質

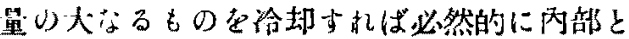
外部に於ける冷却速度に盖を生することであ つて，熱傳導奉り大なるもの程このマスエ フェクトは小さいこととなる。次に金相學的 にマスエフェクトを云々ー心時には先つ第

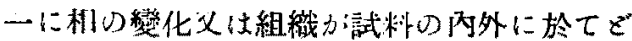
い程度に杖造のあるか指す。この差が大て あればマスエフェクト少大であると云ふこ とになる。伶却り途中に於て少しす異相變化

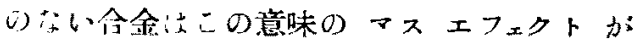
ないこととなる。異相變化施ある合金で虫多 少ともマスェフェクト仿現机る。この異相 變化の進行份却速度に著しく影響される。 り程マスエフェクト少大で, 餘り影響され ない程 マスエフェクト紋々ととにな

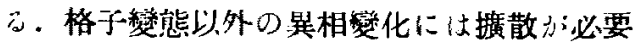

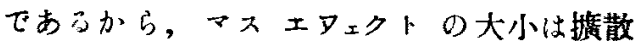
の踓易に文配るれる。愅散少:非常に速いか非 常に避いもし去マスェフェクトか殆どない こととなるが,その中間の顀散度のものては 陚料の大いさによつて種々の程度にマスエ フェクトか現㣗ることと济る。

鋼起燒入する瑒合のアスエフェクトとし $て$ 牥，マルテン化の程度心・・番問題となるか ら，自硬性の鋼は非自硬性の銅に比べてマス エフェタト扔小と云ひ得う。缷散の非常に 速いものはマルテン化しにくいからこの場合 問題とならない，從つて マスエフェクトの 小なる鋼を求めるには

(1) 熱集紫の大心方の。

(2) 嚒散い小尔るもの.

（3）狀態圖的に $A_{5}$ 及び $A_{1}$ 變態の溫度主 
トげるすし。

以上のやう性質さ有上る特殊元素を求如れ ばよい（1)〜 (3) の何机の影響か大大であるか 估個々心場合に就いて考へればよからう。

各種特殊雵に於て二多ルの代用元素々求 めるに仿これらの銓に於て二ッケルが如何 なる役割を持つものであるかね明らかにせな

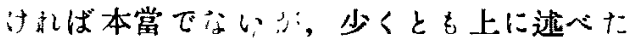
ニカタルォ愅散の避いことはこの重要なる性 質の一つと考へられるであらうから，代用元 素としてはこの性質き持っことが必要と云 ひうるでらう。

\section{\$2. 水・油冷と残留オーステ ナイトの多少}

鋼の燒人に際し，水燒入よりも油燒入の方 シ，殘留オーステナイトの分量名多いこと 沈，よく知られてるる事栖であ己。從來の侤 へ方によれ代，急泠の仕方の大方程オース テナイト拸量に殘留する筈であるから，上 に述べた現像は奇異に臨じられ，諸學者の興 味せ引き，多くの研究かなされたのであつ た。その結果この現象の說明として次のやう ふ事柄か擧げられてるる。

（1）歪說 然留オーステナイトに常溫に於

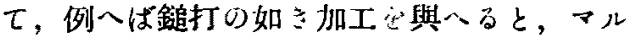
テンサイトに變化することは多くの實驗者に

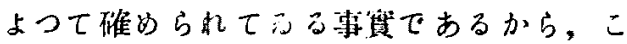
れを以て說明世んとするのか歪說である。試

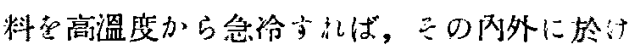
る祫却速度の差よりして試料は辱力の作用定 受する。こり作用は急冷り程度の大なる程大 である。從つて水燒入では一・旦過冷せられた
・オーステナイト抄，この熱霆によつて更にマ ルテンサイトに變化する。油焼入ではこの正 が少いからマルテンサイトへの變化す少い。 從つて水燒入よりも油燒入の方がーステナ イトか餘計に残留すると說くのである。この 說は需の大いさの測定か困難なのと, 試料の 大いきによつて歪の大いさが異なるのでこ れのみでは不十分とせられ，更にマルテン化 の際の膨脹による歪をも扣算して種々の說明 が試みられてるる有樣であるが，一義的な證 明は出來てるない。

前述の鎚打によるマルテン化は間違のない 事筫であるから，外にこれ以上の說明もない 今日，十分ではなにしても先つこの歪說か 採用せられてるる次第である。

（2）瓦斯膜說 試料をよく磨いた場合に は，水燒入に際してその表面に水蒸氣の膜が 附着して，その部分の冷却速度が僬くなる場 合执ある。これ防くために表面に碈の粉の 如さの在塗ることは周知である。この現象 を借用して，油燒入の場合には斯㥞な膜が出 來にくい汃ら水燒入よりも却つて冷却加早い 部分があつて，てのためにオーステナイトが 餘計に殘留するであらうと說明するのであ る。この說もそのやう場合がいとは云へ

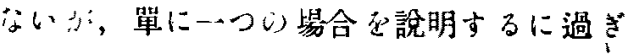
す, 歪說上ら毛微力である。

（3）新理論 新理論によれば，この現参は 極めて當然の事板であつて，特に說明を必荘 とせない位である。

IV.\$1.（2）に逃心た如く，燒入か不完全な. る場合，言ひ撸一礼ば急冷の程度か稍：足り 
ない量合に於ては，冷却の途中に $\mathrm{A}_{3}$ 變熊か： 起ることがある。その結果元よりも奖素の多 いオーステナイトか出來ることとなる。然る に第 8 圆に示す如く，オーステナイトの炭素 量の多い程殘留(第 8 通に關与万說明莟照)し 易いのであるから，燒入か:不完全な程オース テナイト招餘計に殘留する理である。郎ち燒 入の如き急冷操作に於 $\tau$, 急冷の度合の小さ い程オーステナイト招く殘留する。こ能水 椧よりも油椧の方にオーステナイトか多く残 留する理由であっ。

若しも憢入液の溫度がこのものの格子變態 點より高い場合に心急冷なる程オーステナイ トか餘計に殘り，急冾の度合少少いと涂中

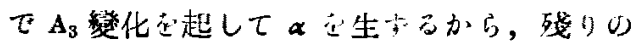
オーステナイトい分量汃少いこととなる。即

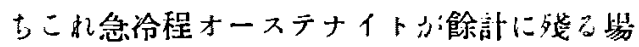

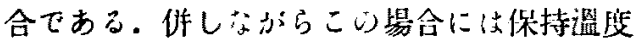
が格子變態點以上であるから，マルテンサイ

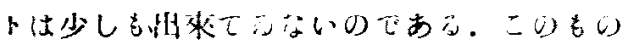

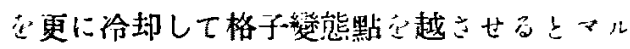
テン化が始る. 斯くはれば急泠せるもり程餘 計にマルテンサイト怘生し，急冷度の小心 もの程オーステナイト稌計に䇅留するのさ ある.斯樣に急冷度の大小と殘留オーステナ イトの多少との開係は，燒入液义は保持する 溫度か格子變態點より离いか低いかによつて 反對となる（㘎衫に云ふならば，残留オース テナイトの多少を定めるもの统, 過冷オース テナイトの組成と分量とである。組成として 法炭素の多い程餘計に线留けることとなる。

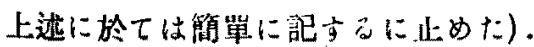

\section{\$3. 高速度錭の㨬戻時效後の} マルテン化に就いて

高速㡲链仕これ采高溫度加ら急冷すれば焼

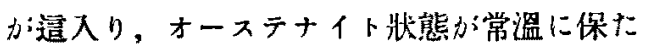

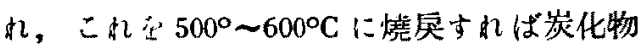

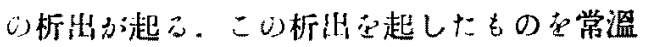
まで朎却子れれ゙更にマルテン化把起る。若し

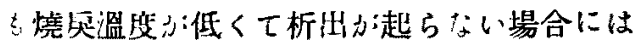
そのもの伶却してもマルデン化は起らな い. 趴ちマルテン化起すには高溫に於ける 析出か，必要保件のギうである。これらの事筫 は筒速度鋼の高溫硬度少; 何によつて得られる ものであるか㫜らかにしてふる點で興味が

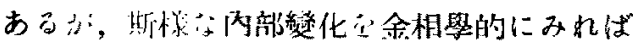

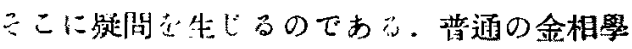
的知識によれ代高㴵燒实に際して起心析出は オーステナイトよりり初析油現象と考人られ むからこの後に起む反應はこの初析晶を含 む尖析變化であるか义心初析晶とオーステナ イトとひ包析反應てなけ級はらない。これ

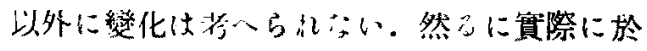
てはマルテン化施建るのみでこのマルテン化 反倠と初析晶とし閶には何等上述の如き關係 分存在してシ济い，從うてこの高速度鋼の變

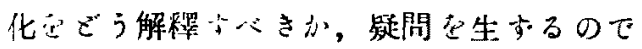
おる.

然るに毁に逃へて来た如く，オーステナイ

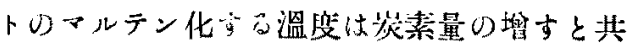
に低くなるから，高速度鎆さ普通に燒入れけ

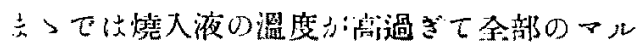

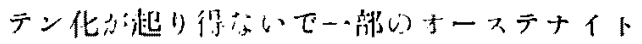

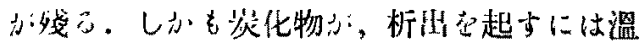




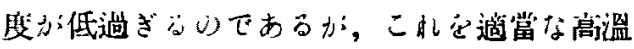

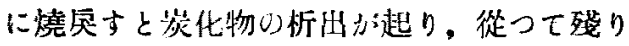
のォーステナイトは炭秦に乏しくなつて來, 從つてマルテン化の溫度か常溫以上となり析 出後の泠却に際してマルテン化するのであ る. 炭化物の析出に續いて起るぐき變化は, 例へば $\mathrm{A}_{3}$ の如き析出變化と考へられるか， これが進行速度か避いため其現なることなく して低桨素オーステナイトが a相准安定䩪 圍にまで過冷せられたけめにマルテン化郎ち 格子變態を起したものと考へられる。

從つて析出起きないオーステナイトす常 溫以下で十分に冷却すれば, $\alpha$ 均一相の籍園

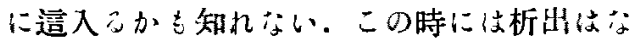
くともマルテン化は起る。叉オーステナイト 狀態加ら常溫に燒入せ歺とる, 適當な高溫ま

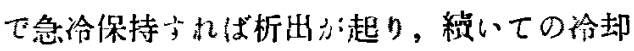
によつてマルテン化が起ると考へられる。

\section{\$4. 鐵-ニッケル合金の所謂非可逆性。}

・鐵一ニッル合金に於ては，その $\mathrm{A}_{3}$ 變態點 积第 2,3 圖に示す如く, 加熱と冷却とで著し く異なり，その程度はニックルの多い程甚だ しいここの現象や鐵一ニッケル合金の非可证恻: と名付け，已の原因に就いて多くの研究か心 されてみる少，今日迄にはまだ十分なる解决 ふついてあない。

一般に，異相變化の溫度放;熱と冾却とで 異なること文，珍しくないことであり，殊に 鎆に於てこの傾向か著しい，從つて加熱の變

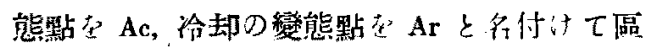
别してるる位である。鐵ーニッタル命昘の $A_{3}$ 變態の場合:法，洞にふお如くニッケルの多

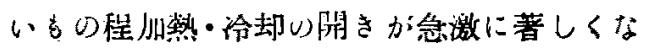
つて居り，加熱・伶却必如何程進くしても, この開き少小さくならいのて非可逆現象と して特に砳究せられてひるのである。これに 關する從來の研究の中には、ニッルルの多い 合金に於て普通の $\mathbf{A}_{\mathbf{3}}$ 變態少進行しにくく， しが低温に於てマルテンサイト栐り組織物

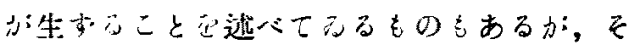

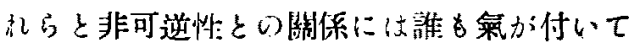
るない。

この問題も吾々の理論によれば容易に解决 せられうのである．先ず普通の $\mathbf{A}_{3}$ 變態が起

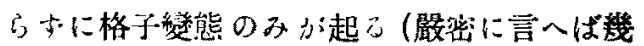
分六普通の $A_{3}$ 變態毛起つてるるかも知れな い.果してごうであうかはIV.\$1. (3)に述 ベたマルテン化の溫度區間の意味が明ら加に なら始ばはつきりしたこと沈言へない)場合， 郎ちニッケルの相噎に多い合金(又はえれより も少い气の多少早く冷却)に就いて述ふん に，こ.のものは朎却の際には，GA線を越して 變態始め，相當の溫度區間冷却と共に變態 か淮行して完結する。この變態の始めと終り の温度さとると，GA線及びそれ以下の溫度 となる.次に全く變態さ終つて $\propto$ となつたる の封加熱すると，GA線に達しても普通の $A_{3}$ 變態き起きう，GB線り越して始めて格子變 態にょつて $\gamma$ を生し，或溫度區間を經てこの 變態が終る．從つてこれらの冷却・加熱に於 ける變態の始りと斜りをとれ代著しい溫度の

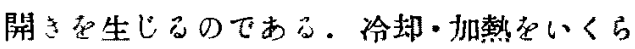
幄くしても二ックルの多い命金では㱠ど普通 の $A_{3}$ 變態は起らなくて，格子變態のみか起 
るからこの溫度の開きは小くならない。 その代りに急陯・急熱してもこの開き法人き

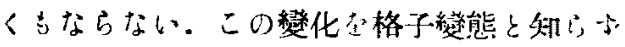

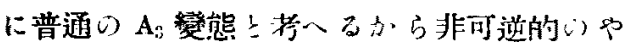

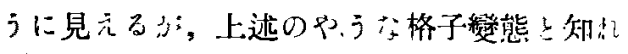

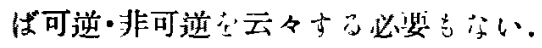

次に更に二っヶルの少い塄命汇就いて述心 んにこの場命には伶却・加熱芯早くして行

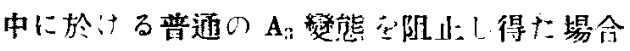

に汢全く上る同桄の現象が起る。途中で多少 とも $A_{3}$ 變態方起心易命にはこの $A_{3}$ 變熊と

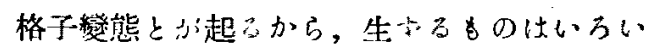

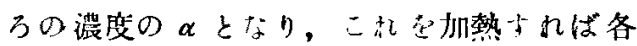

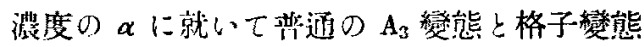
上が起方分，加熱と冷却々が一致し難く，

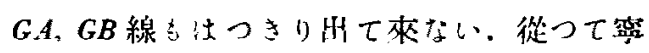

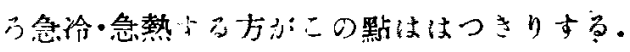

\section{VI. 一般合金の熟處理燓態理論}

本論交の冒頭に逃べけ如く，著者等は铜の 熱處理のみならす，廣く一般合金に就いて熱 處理に伴なふ合余の队部變化敌研究しつつお るのであつて，マルテンサイト生成の機棈先 前節に述へたやうに結論したのは，命金全般 の通性の一つとしてであつて，鋼のみの研究 によつて得られだ結論ではがのである。本 節に於ては一般合金坴熱處理する場合の內部 變化節ち熱處理變態の理論に就いて述へる こととなる.先づ其析合金の燒入から䛦明し \pm 5 .

\section{\$1、共析合金の燒入}

著者等の研究以前に於ては，マルテンサイ トは狀態㘣に現すことの出來ない相とせられ てるた．刨ち $A_{1}$ 篎態の部分的進行によつて 生じだ間狀態であるとせられてうれ。而し て斯樣な中間狀態の出現は銅に煺られたもの

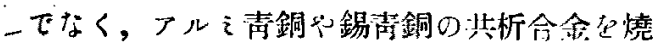

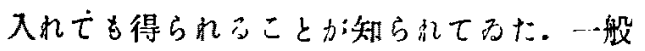
に合金の研究としては全䯈的に見て銅の郡究 がの大部分て，その他の合金の研究は叙
に比べればミの數が少いそれ故に鋼で知ら れてるる事柄は他の合金にも掌岸ると解釋せ られる場合小＼cjkstart多い。この中間狀態当鋼で發 見せられ，次いで青銅類で發見せられ，しか もミれらの中間物がルテンサイトに似た組 織有してるふりで，斯榚な中間狀態尼生す

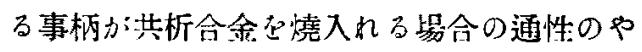
うに考へられて來たのであった。併しなから 著者等は前節迄に述べて來た如く，鐵ーニッケ

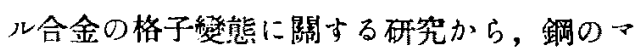
ルテン化をる同樣の格子變態によるものとの 豫想さつけてるたので，斯㥞な中間物索生す。 るのは總べての垬析合金に起る現象てはなく

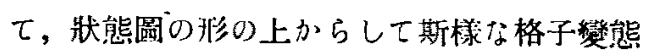
の可能となるやうな形の狀態圆各有する場合 に於てのみるの現か：可能て，然らざる場合 には其析命金乍燒入れても，斯榚な中間狀態 は生じないであらうと豫想した，從つて各種

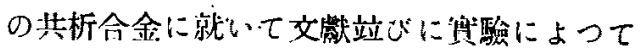

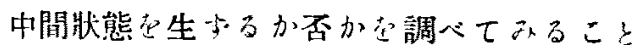
とした. 
比榕的上く研究せられてるる其析合金とし

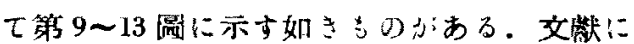

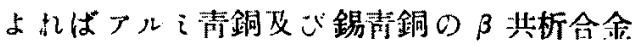

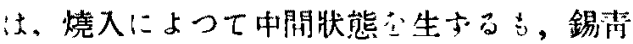

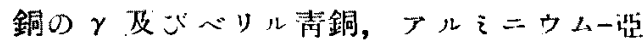
鉛, ニッケルー亞鉛，インデウム青銅等の合昘

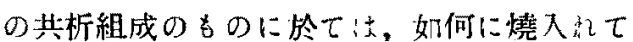
る高溫安定の狀態か常溫に迄過冷せられっの。 みで, 、ルテン組織の中開物は得ら岵ないの

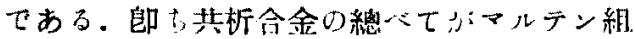

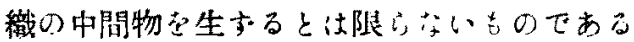

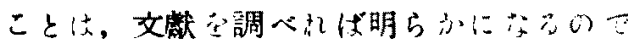
ある。

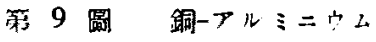
合金狀照掏

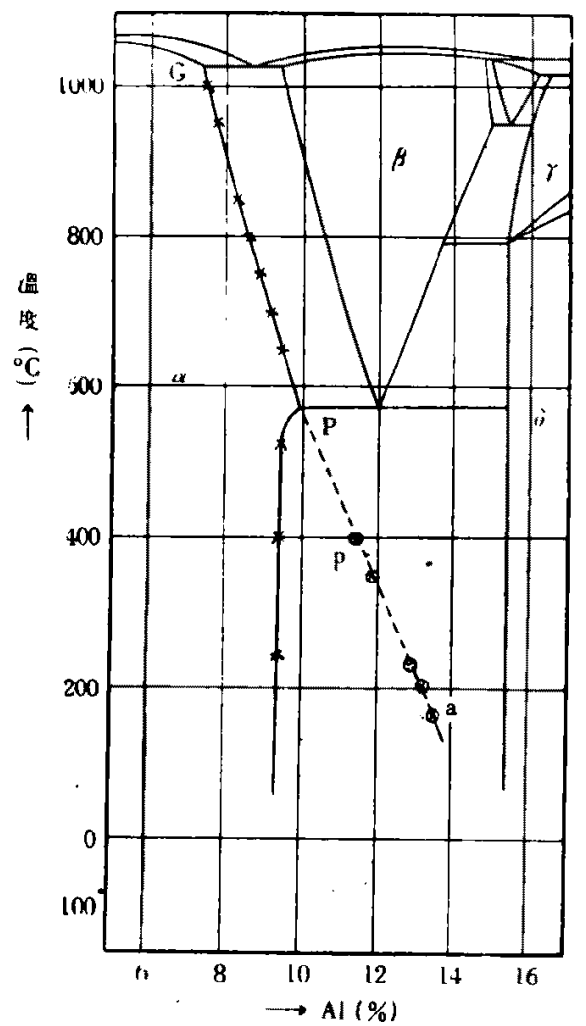

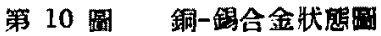

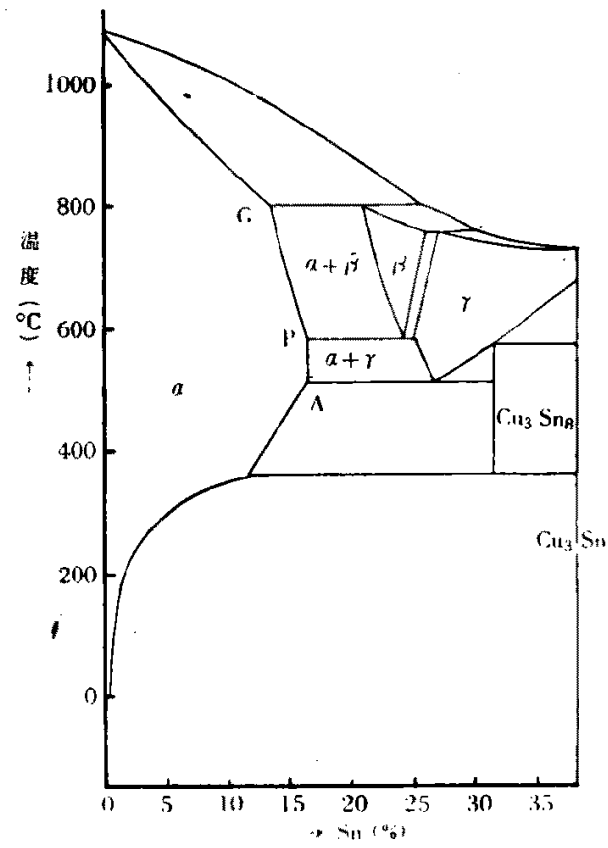

第 11 圆鎆ーインヂウム合金

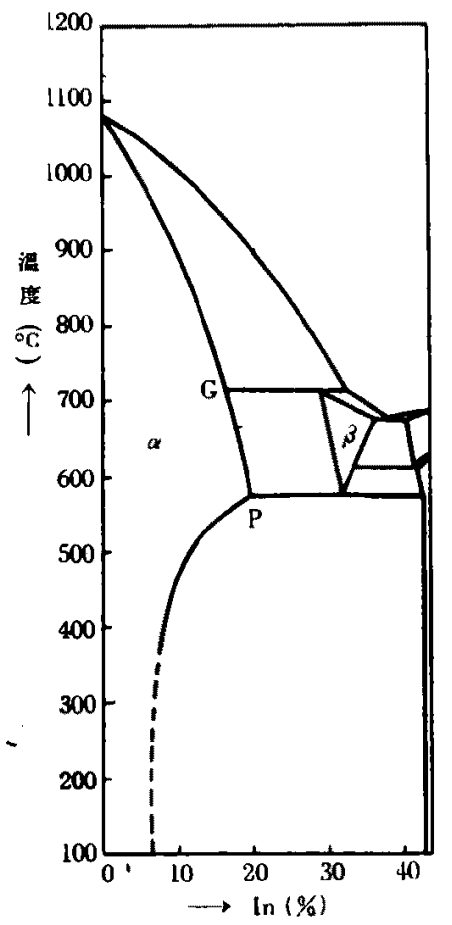




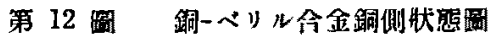

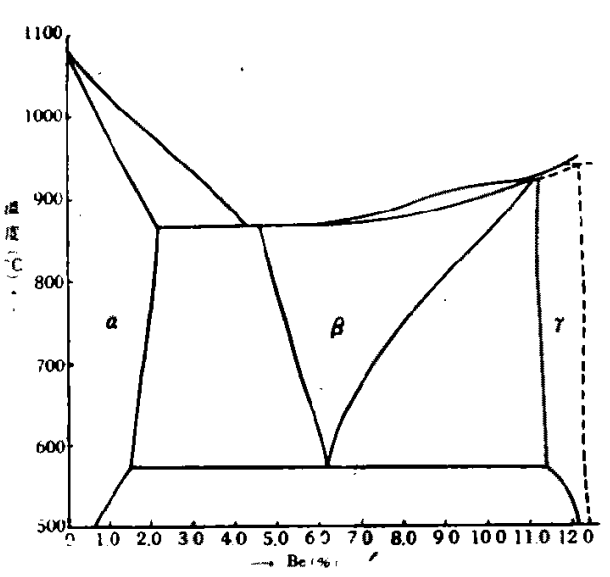

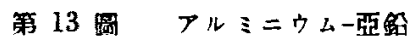
含金狀態圆

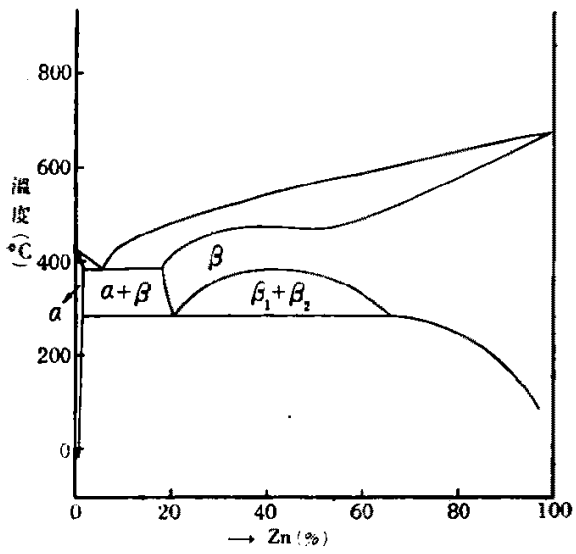

第 14 圖及心゙第 15 圖は共析合金の狀態眗の

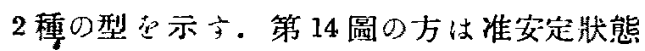

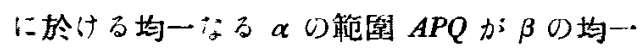

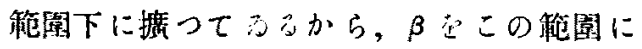

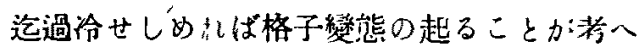
られる.アル氵青銅に於て中開物の生成溫

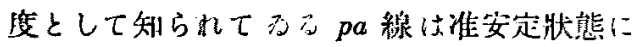

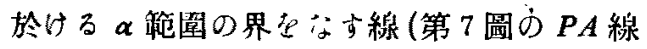
に䈏る)と見られる位置にある。從つてこの 場合のマルテン式組織物は $\boldsymbol{\beta}$ が格子變態に

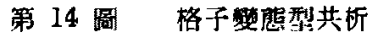
合金狀態佪

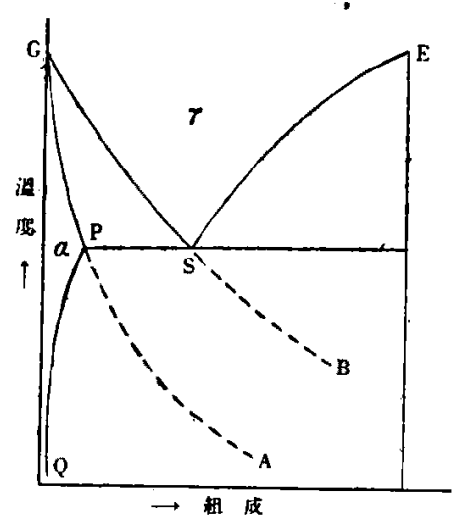

第 15 圖滑命型共析合金狀㦔四

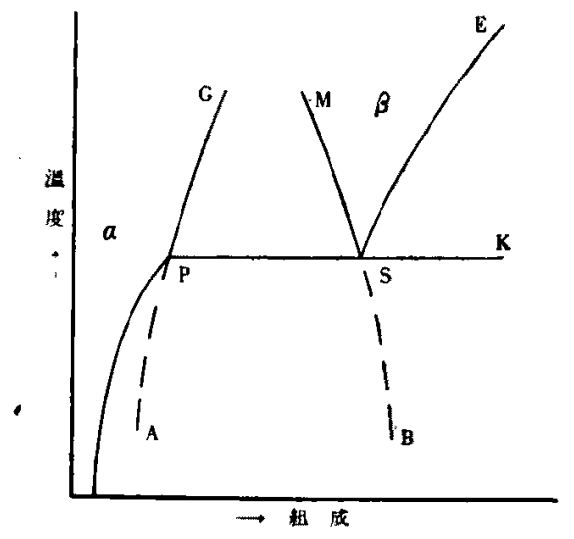

よつて准安定のаとなつたきのと考へられ る. 又錫青銅に於 $\tau \alpha, \beta 2$ 相共存筙園の境 界線の一つGP 延長すれば，准安定 $\propto$ の

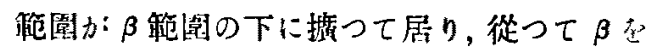
急冷してこの筑園に迄過佮せしめて，格子變 態象起さしめ得ることが考へられる。こら

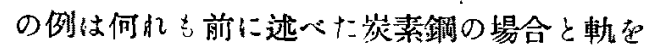
同しくしてるっ，從つてこれらの命金に現れ

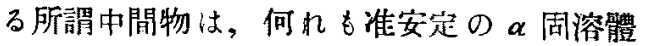
であつて，狀態國中に現れ得るものであり， 合金の通惟として斯梯な准安定相它生する。 


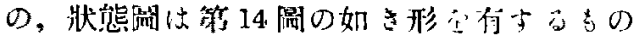
であるこる扒結满上りれる。

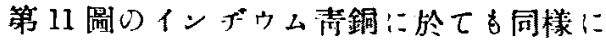

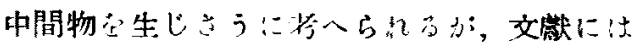

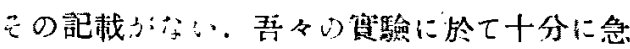
冷して液體空氣の溫度に迄伶却したのてあつ

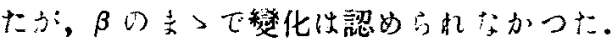
この結果から見记ば $G P$ 線の延長少液體室氣

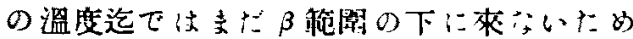
であらうと将へり虬う。

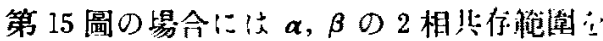
區切つてるる線心延長伿，互に遙ざかる。

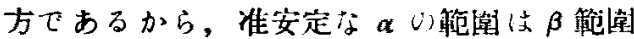
の下に來标い，㝘ひ换八れば $\beta$ 如何に過 冷せしめてもPA 楾点越させることが出來な

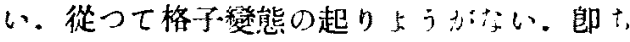

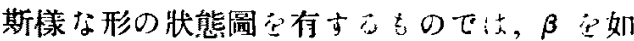
何に急泠して $\beta$ 小過冷せら机えのみて中

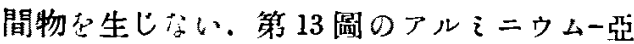
鉛合金はこの㤠の共析合金である，又第 12 圆のベリル青銅も同樣である。交獻によれ ば錫青銅の $\gamma$ 合金ち中閏物さ生しないとせ られてうるか，狀態圖の形から見れば冨然で ある。錫青銅に於て $\beta$ と $\gamma$ の組成の相違は 僅かであるにも拘らな，一方公中閒物を生し， 他はこれ勧生しないのであるふ，吾々の理論 によればこれらの現象は满足に說明せら れる。

以上速心た如く，共析合金に於て十分なる 急泠によつて, 高溫安定の狀態低低溫に迄過 冷せしめんとする時，中間狀態它生るる加否

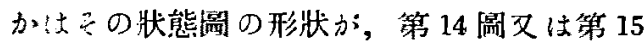

風の中の何れであるかによつて定まると云心 一つの原则的事實距明らにし得てのである。

\section{$\therefore \quad \$ 2$. 時效性合金の愤入}

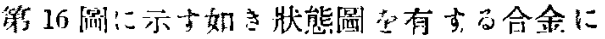

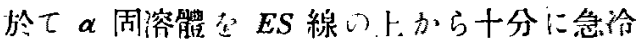

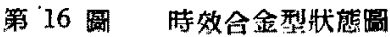

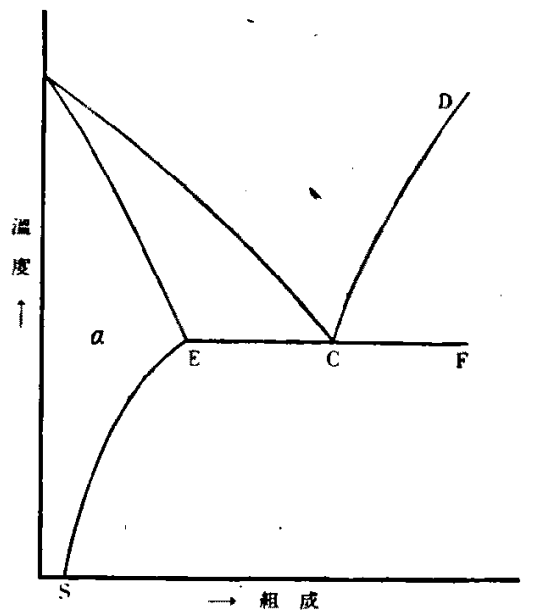

すれば均一なる 效性合金の憢入現象である。この場合高溫安 定の狀態か低溫に迄持來たき能るのであるか ら，この現像敒第 15 圖型の共析合金の燒入 の場合と等しいこととなる。狀態圖からみて

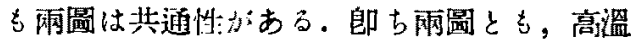
安定相が格子變態起起し得るゃうな形をなし てるないのである。言ひ換へれば共析合金に 就いてミ1.に述心゙事柄か，その他の合金に も適用せられることか知られるのである。從 つて一般合金の熱處理變惉に就いて次のこと 旅はれるのである。

\section{§3. 烓の這入る・這入らないと 狀態圆との關俰}

上に述心゙て来た事柄か，らして，燒の這入 
る・這人らないと狀態圆との間の關係が明ら かになる。

一般に燒か㯰入ると云云昜合には，高媼の 狀熊がそのま〉過冷せられて低溫に持來たき

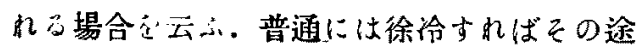
中で變化起し易いから，燒け入れるには急

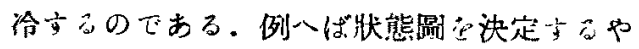

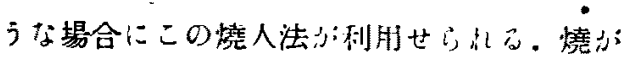
這入らないと云六りは，急冾しても途中の變

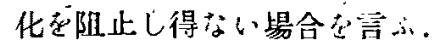

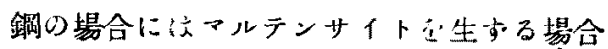
を燒入ると云ふふ，これは上に述ぶた般の 場合から云ふと途中で變化加起つたのである

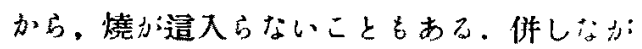
ら鋼の場合にはこれらの言葉は比較的不精滵 に用ひられてるる泘がある。例へば曆狀組織 の一次トースタイトやソルバイトね生する

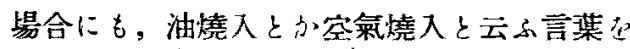
使つてるる。この場合には徐冾の場合上りも 著しく硬いもの得られさから，嚴密には急 冷硬化と言ふぶきとこうき簡單に燒入と言つ てるるのである。文或種の特殊鎆に於ては,
徐冷をればオーステナイト赾分解して了ふ 加，急冷すればそのオーステナイトを常温に 持來たし得る場合がある。この時にも燒が這 入ると言つてるる.從つて鋼の場合には燒か; 這入る・這入らないの意味か科定せないか， 一般に仗途中心變化の有無によつて區別する の少制り易いであらう。

一般に燒少逼入るには，先づ第一に徐伶の 際の變化加阻止せられなければなら急泠 してもこれ租止しにくいものは燒办這入り にくいことと方るここは主として摭散の難 易によるのであるから，その方面から檢討さ

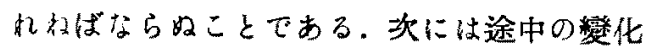
を阻止し得たとしても，その合金の狀態圖の 形状からして過冷せられた相か格子㱍態を起 し得るやうな場合には燒が這入らないことと なる、格子變熊を起し得ないゃうな狀態圆と なつてる机ば燒か逜入る. 即ら第 15 圖及び 第 16 圖型の合金は燒が這入り，第 3 圖及び 第 14 圖型の合金好燒が這入らない.勿論後者 に然ても急冾保持する溫度次第では燒少這入 ることは既に共、述べた通りである。

(終) 